\title{
In-Situ Environmental Gamma Radiation Monitoring at Ramna Thana, Dhaka, Bangladesh
}

\author{
M. S. Mian ${ }^{1}$, M. S. Rahman ${ }^{2}$, J. Islam ${ }^{1}$, K. N. Sakib ${ }^{1}$, M. M. Tasnim ${ }^{1}$, S. Yeasmin ${ }^{2}$ \\ ${ }^{1}$ Department of Physics, Mawlana Bhashani Science and Technology University, Santosh, Tangail- \\ 1902, Bangladesh \\ ${ }^{2}$ Health Physics Division, Atomic Energy Centre, 4 Kazi Nazrul Islam Avenue, Shahbag, Dhaka- \\ 1000, Bangladesh
}

Received 19 December 2018, accepted in final revised form 29 May 2019

\begin{abstract}
Environmental gamma radiation dose rates were measured using a digital portable GammaScout detector from April-May 2018. For this, total 22 monitoring points (MP) were selected in the outdoor environment in the area of Ramna Thana under Dhaka city. The MPs were marked-out using Global Positioning System (GPS) navigation. The GPS reading of the sampling locations were varied from E: $90^{\circ} 23.568^{\prime}$ to E: $90^{\circ} 24.895^{\prime}$ and from $\mathrm{N}$ : $23^{\circ} 44.031^{\prime}$ to $\mathrm{N}: 23^{\circ} 45.018^{\prime}$. The measured dose rates due to natural radionuclides were ranged from $0.115 \pm 0.042 \mu S v \cdot h^{-1}$ to $0.186 \pm 0.051 \mu S v \cdot h^{-1}$ with an average of $0.145 \pm$ $0.044 \mu \mathrm{Sv} \mathrm{h}^{-1}$. The annual effective dose to the population from outdoor environmental gamma radiation was varied from $0.201 \pm 0.073 \mathrm{mSv}$ to $0.326 \pm 0.090 \mathrm{mSv}$ with an average of $0.255 \pm 0.073 \mathrm{mSv}$. This kind of study is required to detect the presence of natural radionuclides and artificial radionuclides (if any) releasing from nuclear and radiological facilities in the country or from neighboring countries for normal operations or in case of accident/incident. From this study, it can be concluded that there is no radiation burden to the environment due to man-made sources.
\end{abstract}

Keywords: In-Situ; Gamma radiation; Dose rate; Gamma scout.

@ 2019 JSR Publications. ISSN: 2070-0237 (Print); 2070-0245 (Online). All rights reserved.

doi: http://dx.doi.org/10.3329/jsr.v11i3.39318 J. Sci. Res. 11 (3), 263-272 (2019)

\section{Introduction}

The majority of human exposure to ionizing radiation occurs from natural sources including cosmic rays and terrestrial radiation [1]. Exposure to extraterrestrial origin radiation, galactic cosmic rays and energetic particles from solar particle events depends mostly on geographical characteristics of a place such as altitude, latitude and solar activity [2,3]. Natural radionuclides of terrestrial origin have very long half-lives or driven from very long-lived parent radionuclides which have been created stellar processes before the earth formation. Excluding exposure from direct cosmic rays and cosmogenic radionuclide from extraterrestrial sources, natural exposures arise mainly from the

\footnotetext{
Corresponding author: msrahman74@ hotmail.com
} 
primordial radionuclides such as ${ }^{238} \mathrm{U} \&{ }^{232} \mathrm{Th}$ series and ${ }^{40} \mathrm{~K}$ which are spread widely and are present in all most geological materials in the earth's environment [4,5]. Unlike the pollutants with anthropogenic sources that are introduced into the environment through human activity [6], terrestrial origin radionuclides are naturally present at trace levels in all environmental compartments. Most radionuclides in the uranium series, thorium series and ${ }^{40} \mathrm{~K}$ emit gamma radiation giving rise to human exposures from gamma rays outdoor. Gamma ray accounts for the majority of external human exposures to radiation from all type of sources due to its high penetration ability [7]. Gamma radiation is ubiquitous. Great variations have been observed in environmental radiation levels and several international studies have been characterized gamma dose rates both in outdoor and indoor environments [8-12].

Both laboratory and in-situ gamma spectroscopy are often used for monitoring and assessment of radioactivity and radiation dose rates in the environment due to both natural and anthropogenic sources [13-18]. In-situ techniques for measuring the activity concentration resulting from the gamma radiation and characterizing its sources with gamma ray spectrometer have been used successfully in the outdoor environment [13,1921].

The presence of naturally occurring radionuclides in the environment may result in an external and internal dose received by a population exposed to them directly and through the ingestion and inhalation pathways. The assessment of the radiological impact on a population as a result of the radiation emitted by these radionuclides is important since they contribute to the collective dose of the population [22]. The In-situ gamma-ray dose rate measurement is highly reliable in indoor and outdoor environments [23]. The radiographies, CT and X-ray investigations can protect life but their high level radiation doses can affect people health [24]. This type of study is very important for radiation protection purpose in the country because the usage of radiation sources for diagnostic and therapeutic purposes in hospitals is increasing day by day. It is mentionable that several largest hospitals, notably Bangabandhu Sheikh Mujib Medical University Hospital is situated within the boundary of Ramna Thana and BIRDEM Hospital is situated in the Ramna Thana. In addition, many people with their children used to visit Ramna Park and Shishu Park for recreation. These two national Parks are also located in the Ramna Thana. The aim of the present study is to measure the environmental terrestrial gamma radiation dose rate at Ramna Thana in Dhaka city and to determine the annual effective radiation doses to which people are exposed from terrestrial gamma radiation.

\section{Materials and Methods}

\subsection{Description of the site}

The study location was marked out using GARMIN eTrex HC series personal navigator. The unit uses the proven performance of Garmin high-sensitivity GPS and full-featured mapping to create an unsurpassed portable GPS receiver [25]. The study site is located from E: $90^{\circ} 23.568^{\prime}$ to $E: 90^{\circ} 24.895^{\prime}$ and from N: $23^{\circ} 44.031^{\prime}$ to $\mathrm{N}: 23^{\circ} 45.018^{\prime}$. Twenty two 
locations were selected for measurement of outdoor environmental gamma radiation dose rates at Ramna Thana in Dhaka city. Ramna thana area 3.42 sq.km, population 200,973 (male: 108,262 and female: 92,711), population density 58,764/sq.km [26]. Important installations of Ramna Thana are BIRDEM Hospital, Ramna Park (1947), Children Park, State Guest House Meghna, State Guest House Jamuna, Residence of the Chief Justice, Dhaka Officers' Club, Office of the Dhaka Metropolitan Police Commissioner and Directorate of the Public Health Engineering. The country's biggest medical university 'Bangabandhu Sheikh Mujib Medical University is situated adjacent to the Ramna Thana.

\subsection{Description of the apparatus}

A real-time digital portable radiation monitoring device which is known as GAMMA SCOUT was used for this study. GAMMA SCOUT is German designed and manufactured, built with a solid Novadur exterior. An optional stylish leather holster with belt strap can further protect the GAMMA SCOUT from the elements. The GAMMA SCOUT meets all European CE standards as well as US FCC 15. All units come with an industry leading 2-year manufacturer's warranty and a serialized test certificate. The GAMMA SCOUT is a fully featured Geiger counter with a form fitting ergonomic shape. The unit has a battery indicator, multiple unit conversion, real-time dose rate and cumulative dose display functions and programmable logging and alert functions. Advanced functions include PC data download via USB cable and an ultra-low current power circuit for extended battery life [27]. The measurements were performed every day at 04 (four) MPs from April-May 2018. For each location, the real-time digital portable radiation monitoring device (GAMMA SCOUT) was placed on tripod at $1 \mathrm{~m}$ height and time for dose rate measurement was $1 \mathrm{~h}$. Fig. 1 shows the location of Ramna Thana in Dhaka city where outdoor environmental gamma radiation measurement was performed using a digital portable radiation monitoring device through In-situ technique. Table 1 gives the description of monitoring points (MPs). This site was marked out using Global Positioning System (GPS) navigation.

\subsection{Calibration}

The GAMMA SCOUT was calibrated inbuilt by the manufacturer. The GAMMA SCOUT is also calibrated at the Secondary Standard Dosimetry Laboratory under Bangladesh Atomic Energy Commission using gamma-ray standard sources. The GAMMA SCOUT accurately measures dose rate in the range of 0.01-5000 $\mu \mathrm{Sv} / \mathrm{h}$.

\subsection{Data taking process and calculation formula}

Environmental gamma radiation dose rates were measured in the area of Ramna Thana under Dhaka city. The measurement was performed using a digital portable Gamma-Scout detector from April-May 2018. The digital portable Gamma-Scout detector was placed at $1 \mathrm{~m}$ above the ground on tripod and data acquisition time for each monitoring point (MP) 
was $1 \mathrm{~h}$. Total 22 MPs were selected for collection of gamma-ray dose rates in the outdoor environment at the area of Ramna Thana as shown in Fig. 1. The MPs were marked-out using Global Positioning System (GPS) navigation as shown in Table 1.

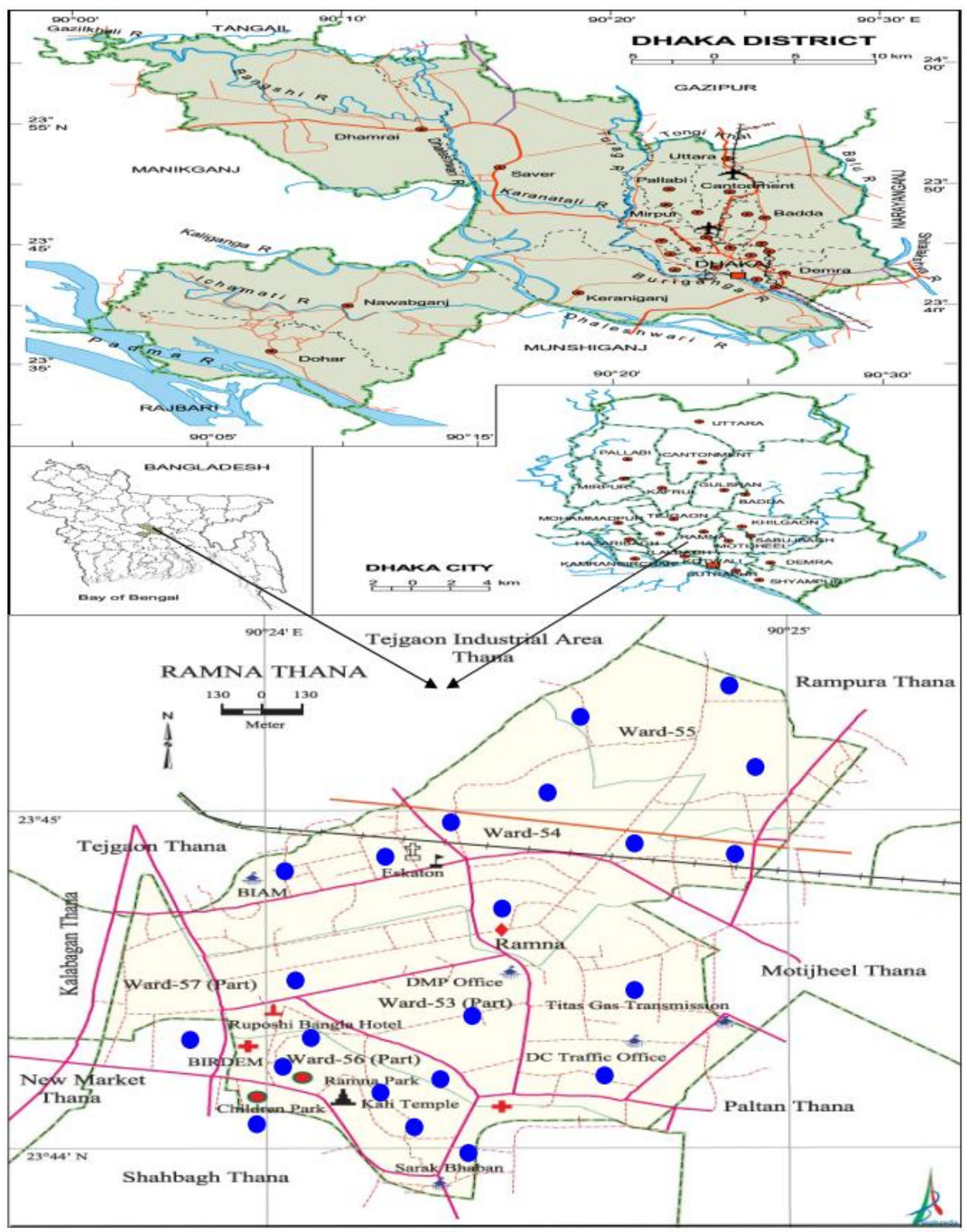

Fig. 1. Shows the location $(\bullet)$ of the Ramna Thana in Dhaka city where environmental terrestrial gamma radiation measurement was performed. 
UNCEAR 1988 [28] recommended the outdoor occupancy factor of 0.20 to population. This occupancy factor is the proportion of the total time during which an individual is exposed to a radiation field at outdoor. The outdoor annual effective dose to population due to gamma radiation is calculated according to the following equation [29, 30].

Annual effective dose $(\mu \mathrm{Sv})=$ dose rate $\left(\mu \mathrm{Sv} \cdot \mathrm{h}^{-1}\right) \times 0.2 \times 8760 \mathrm{~h} \cdot \mathrm{yr}^{-1}$

\section{Results and Discussion}

\subsection{Collection of field gamma-ray dose rate}

Measurement of outdoor environmental gamma radiation dose rate was carried out at the area of Ramna Thana in Dhaka city from April-May 2018 following In-Situ technique. The contribution of dose rates in all monitoring points arising from natural radionuclides.

\subsection{Absorbed dose rate and annual effective dose}

The measured dose rates due to natural radionuclides were ranged from $0.115 \pm 0.042$ $\mu \mathrm{Sv} . \mathrm{h}^{-1}$ to $0.186 \pm 0.051 \mu \mathrm{Sv} \cdot \mathrm{h}^{-1}$ with an average of $0.145 \pm 0.044 \mu \mathrm{Sv} \cdot \mathrm{h}^{-1}$. Using the conversion factor of $0.7 \mathrm{~Sv} \mathrm{~Gy}^{-1}$ as recommended by UNSCEAR 2000 [31], and considering that people in Bangladesh spend approximately $20 \%$ of their time outdoor and remaining $80 \%$ of time indoor; the annual effective dose received by people in Dhaka city due to the environmental gamma radiation is given in Table 1. The annual effective dose rates of the population due to the outdoor environmental gamma radiation were also calculated and it was varied from $0.201 \pm 0.073 \mathrm{mSv}$ to $0.326 \pm 0.090 \mathrm{mSv}$. The mean annual effective dose was found to be $0.255 \pm 0.073 \mathrm{mSv}$. Moreover, environmental radiation and radioactivity monitoring is crucial to generate the baseline database from natural sources before starting operation of the country's first nuclear power plant. The national baseline database is very important for comparison before and after operation of the nuclear power plant. This study is very useful to know the artificial radionuclides releasing (if any) to the environment from man-made sources like hospitals. Therefore, real-time gamma radiation measurement is very vital in and around radiological facilities (hospitals) for the safety of the public.

Table 1. Outdoor dose rate and annual effective dose due to gamma radiation at Ramna Thana in Dhaka city.

\begin{tabular}{|c|c|c|c|c|c|c|}
\hline \multirow{2}{*}{$\begin{array}{l}\text { MP } \\
\text { No. }\end{array}$} & \multirow[t]{2}{*}{ Name of Place } & \multirow{2}{*}{$\begin{array}{l}\text { Latitude/ } \\
\text { Altitude }\end{array}$} & \multicolumn{3}{|c|}{$\begin{array}{l}\text { Gamma dose rate } \\
\left(\mu \mathrm{Sv}_{\mathrm{h}} \mathrm{h}^{-1}\right)\end{array}$} & \multirow{2}{*}{$\begin{array}{l}\text { Mean annual effective } \\
\text { dose due to gamma } \\
\text { radiation }(\mathrm{mSv}) \pm \mathrm{SD}\end{array}$} \\
\hline & & & Range & Mean & SD & \\
\hline \multirow[t]{2}{*}{1} & BIRDEM & $\mathrm{N} 23^{0} 44.322^{\prime}$ & $(0.08-0.20)$ & 0.14 & 0.039 & $0.245 \pm 0.068$ \\
\hline & Hospital & $\mathrm{E} 90^{0} 23.768^{\prime}$ & & & & \\
\hline \multirow[t]{2}{*}{2} & Ramna & $\mathrm{N} 23^{\circ} 44.290^{\prime}$ & $(0.05-0.18)$ & 0.115 & 0.092 & $0.210 \pm 0.074$ \\
\hline & $\operatorname{Park}(1)$ & $\mathrm{E} 90^{0} 23.994^{\prime}$ & & & & \\
\hline
\end{tabular}




\begin{tabular}{|c|c|c|c|c|c|c|}
\hline 3 & $\begin{array}{l}\text { Ramna } \\
\text { Park(2) }\end{array}$ & $\begin{array}{l}\mathbf{N} 23^{0} 44.031^{\prime} \\
\text { E90 }^{0} 24.220^{\prime}\end{array}$ & $(0.07-0.18)$ & 0.125 & 0.036 & $0.219 \pm 0.063$ \\
\hline 4 & $\begin{array}{l}\text { Ramna } \\
\text { Park(3) }\end{array}$ & $\begin{array}{l}\text { N23 } 3^{0} 44.415^{\prime} \\
\text { E90 } 24.031^{\prime}\end{array}$ & $(0.09-0.21)$ & 0.15 & 0.039 & $0.263 \pm 0.068$ \\
\hline 5 & Children Park & $\begin{array}{l}\mathbf{N} 23^{0} 44.209^{\prime} \\
\text { E } 90^{0} 23.975^{\prime}\end{array}$ & $(0.07-0.18)$ & 0.123 & 0.037 & $0.215 \pm 0.065$ \\
\hline 6 & $\begin{array}{l}\text { Ruposhi } \\
\text { Bangla Hotel }\end{array}$ & $\begin{array}{l}\text { N23 }{ }^{0} 44.493^{\prime} \\
\text { E90 } 23.797^{\prime}\end{array}$ & $(0.11-0.20)$ & 0.155 & 0.030 & $0.272 \pm 0.053$ \\
\hline 7 & Kali Temple & $\begin{array}{l}\mathbf{N} 23^{0} 43.872^{\prime} \\
\text { E90 } 23.925^{\prime}\end{array}$ & $(0.09-0.22)$ & 0.151 & 0.040 & $0.264 \pm 0.071$ \\
\hline 8 & Sarak Bhaban & $\begin{array}{l}\mathbf{N} 23^{0} 44.043^{\prime} \\
\text { E } 90^{0} 24.107^{\prime}\end{array}$ & $(0.08-0.20)$ & 0.14 & 0.039 & $0.245 \pm 0.068$ \\
\hline 9 & BIAM & $\begin{array}{l}\text { N23 }{ }^{0} 44.904^{\prime} \\
\text { E90 }^{0} 23.758^{\prime}\end{array}$ & $(0.11-0.21)$ & 0.16 & 0.033 & $0.280 \pm 0.058$ \\
\hline 10 & Eskaton & $\begin{array}{l}\mathbf{N} 23^{0} 44.830^{\prime} \\
\text { E } 90^{0} 23.956^{\prime}\end{array}$ & $(0.08-0.19)$ & 0.135 & 0.036 & $0.237 \pm 0.063$ \\
\hline 11 & $\begin{array}{l}\text { Titas Gas } \\
\text { Transmission }\end{array}$ & $\begin{array}{l}\text { N23 }{ }^{0} 45.018^{\prime} \\
\text { E90 }^{0} 23.568^{\prime}\end{array}$ & $(0.05-0.35)$ & 0.159 & 0.090 & $0.278 \pm 0.159$ \\
\hline 12 & DMP Office & $\begin{array}{l}\mathrm{N} 23^{0} 44.627^{\prime} \\
\mathrm{E}^{\prime} 90^{0} 24.251^{\prime}\end{array}$ & $(0.11-0.24)$ & 0.17 & 0.043 & $0.298 \pm 0.075$ \\
\hline 13 & $\begin{array}{ll}\text { DC } & \text { Traffic } \\
\text { Office } & \end{array}$ & $\begin{array}{l}\mathrm{N} 23^{0} 44.418^{\prime} \\
\mathrm{E}^{\circ} 0^{0} 24.477^{\prime}\end{array}$ & $(0.10-0.18)$ & 0.144 & 0.027 & $0.252 \pm 0.047$ \\
\hline 14 & Ward 54(1) & $\begin{array}{l}\mathbf{N} 23^{0} 44.500^{\prime} \\
\text { E90 }^{0} 24.406^{\prime}\end{array}$ & $(0.07-0.23)$ & 0.15 & 0.050 & $0.263 \pm 0.088$ \\
\hline 15 & Ward 54(2) & $\begin{array}{l}\mathrm{N} 23^{0} 44.491^{\prime} \\
\mathrm{E} 90^{0} 24.283^{\prime}\end{array}$ & $(0.09-0.20)$ & 0.143 & 0.037 & $0.250 \pm 0.065$ \\
\hline 16 & Ward 54(3) & $\begin{array}{l}\mathbf{N} 23^{0} 44.575^{\prime} \\
\text { E } 90^{0} 24.341^{\prime}\end{array}$ & $(0.08-0.21)$ & 0.145 & 0.042 & $0.254 \pm 0.073$ \\
\hline 17 & Ramna Thana & $\begin{array}{l}\mathbf{N} 23^{0} 44.717^{\prime} \\
\text { E } 90^{0} 24.260^{\prime}\end{array}$ & $(0.04-0.21)$ & 0.127 & 0.054 & $0.223 \pm 0.095$ \\
\hline 18 & Magbazar & $\begin{array}{l}\mathbf{N} 23^{0} 44.915^{\prime} \\
\text { E } 90^{0} 24.207^{\prime}\end{array}$ & $(0.10-0.24)$ & 0.17 & 0.045 & $0.298 \pm 0.078$ \\
\hline 19 & Ward 55(1) & $\begin{array}{l}\mathbf{N} 23^{0} 44.628^{\prime} \\
\text { E90 }^{0} 24.856^{\prime}\end{array}$ & $(0.05-0.18)$ & 0.115 & 0.042 & $0.201 \pm 0.073$ \\
\hline 20 & Ward 55(2) & $\begin{array}{l}\mathrm{N} 23^{0} 44.874^{\prime} \\
\mathrm{E}^{\prime} 0^{0} 24.660^{\prime}\end{array}$ & $(0.10-0.27)$ & 0.186 & 0.051 & $0.326 \pm 0.090$ \\
\hline 21 & Ward 55(3) & $\begin{array}{l}\mathbf{N} 23^{0} 44.700^{\prime} \\
\text { E } 90^{0} 24.895^{\prime}\end{array}$ & $(0.10-0.20)$ & 0.15 & 0.033 & $0.263 \pm 0.058$ \\
\hline 22 & Ward 55(4) & $\begin{array}{l}\mathbf{N} 23^{0} 45.000^{\prime} \\
\text { E90 } 24.773^{\prime}\end{array}$ & $(0.10-0.20)$ & 0.15 & 0.033 & $0.262 \pm 0.058$ \\
\hline
\end{tabular}

Fig. 2 shows the outdoor annual effective dose of each monitoring point was normalized to the minimum annual effective dose. From Fig. 2, it can be seen that the difference of annual effective dose of each monitoring point is not high. The reason for this difference might be geographical characteristics of each location. 


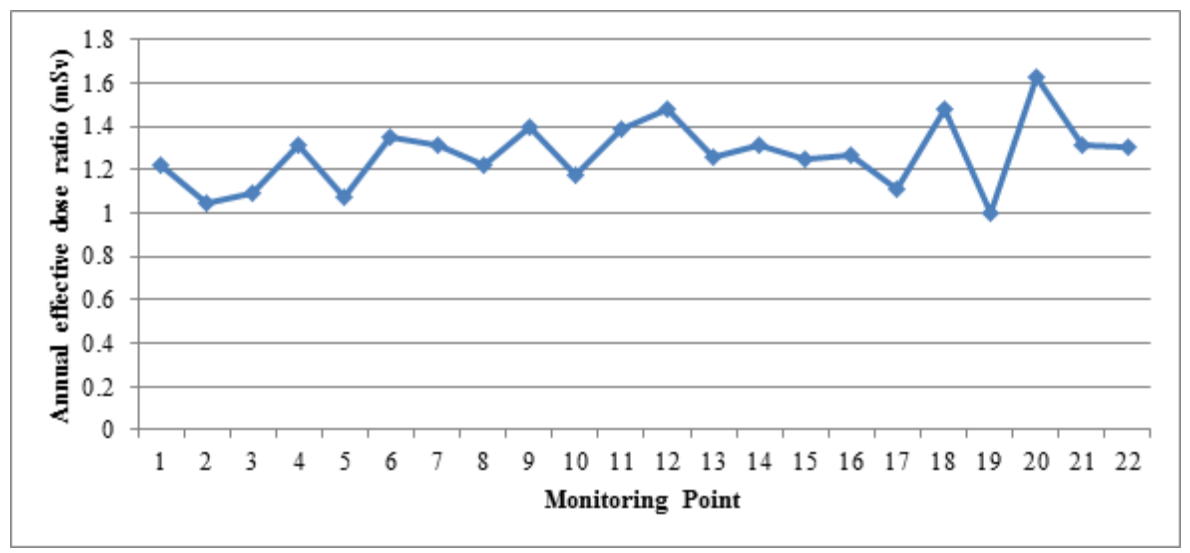

Fig. 2. Outdoor annual effective dose values normalized to the minimum annual effective dose for each MP.

The frequency distribution of the terrestrial gamma absorbed dose rates in air follow a normal type distribution as shown in Fig. 3.

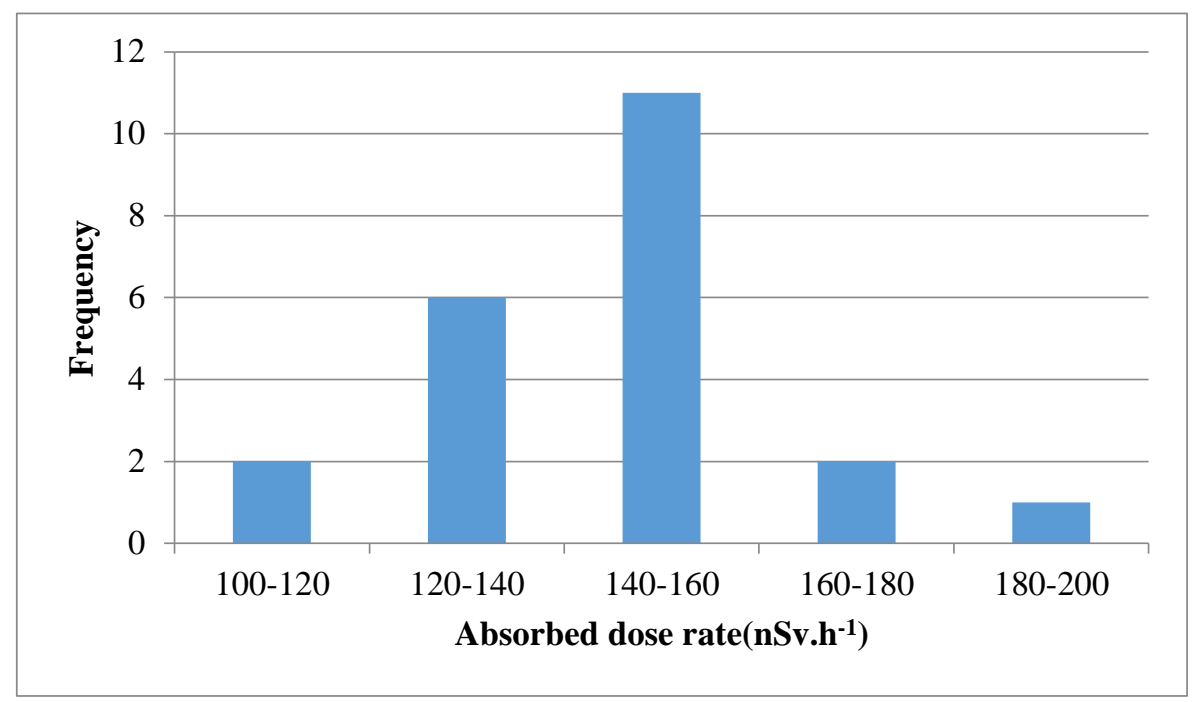

Fig. 3. Frequency distribution of the absorbed dose rates $\left(n S v \cdot h^{-1}\right)$ at Ramna Thana in Dhaka city.

The annual effective dose range due to the outdoor environmental gamma radiation to the population of Dhaka city is tabulated in Table 2. It can be seen from Table 2 that the range of dose rate and annual effective dose to population of Ramna Thana is lower than some countries like Italy, Indonesia, India, China and higher than China (Tibet), Azerbaijan. The exact reason for high radiation doses are not known, but might be attributed to geographical, geological, and altitude of cities studied. The average levels of 
annual effective dose to populations for countries are mostly in the range of $0.30-0.60$ $\mathrm{mSv}$ [32]. The annual effective dose to population in Dhaka city ranged from 0.201-0.326 $\mathrm{mSv}$ which is within the range of worldwide average. The average outdoor environmental gamma radiation dose rate in the study area was found to be $0.145 \pm 0.044 \mu \mathrm{Sv}^{-1} \mathrm{~h}^{-1}$ which is equal to the urban area of Brazil [32].

Table 2. Environmental gamma dose rate range and annual effective dose range due to natural radionuclide sources for selected countries and for this study [UNSCEAR 2008] [32].

\begin{tabular}{llll}
\hline Country & $\begin{array}{l}\text { Range of dose } \\
\text { rate }\left(\mu \mathrm{Sv} \cdot \mathrm{h}^{-1}\right)\end{array}$ & $\begin{array}{l}\text { Mean Gamma dose } \\
\text { rate }\left(\mu \mathrm{Sv} \cdot \mathrm{h}^{-1}\right)\end{array}$ & $\begin{array}{l}\text { Range of annual } \\
\text { effective dose }(\mathrm{mSv})\end{array}$ \\
\hline $\begin{array}{l}\text { Brazil (Pocos de Caldas, MG, } \\
\text { Urban areas) }\end{array}$ & $0.093-0.244$ & 0.145 & $0.163-0.427$ \\
Italy (Lazio) & $0.120-0.270$ & 0.175 & $0.210-0.473$ \\
Indonesia (Karimu Island) & $0.200-0.410$ & 0.310 & $0.350-0.718$ \\
China (Tibet) & $0.080-0.140$ & 0.121 & $0.140-0.245$ \\
India (Odisha) & $0.251-0.879$ & 0.449 & $0.439-1.540$ \\
Azerbaijan & $0.075-0.205$ & 0.140 & $0.131-0.359$ \\
China & $0.011-0.523$ & 0.815 & $0.019-0.916$ \\
This Study & $\mathbf{0 . 1 1 5 - 0 . 1 8 6}$ & $\mathbf{0 . 1 4 5}$ & $\mathbf{0 . 2 0 1}-\mathbf{0 . 3 2 6}$ \\
\hline
\end{tabular}

\section{Conclusion}

The present study has measured the real-time outdoor environmental gamma radiation dose rates at Ramna Thana in Dhaka city. The average outdoor environmental gamma radiation dose rate in the study area was found to be $0.145 \pm 0.044 \mu \mathrm{Sv}_{\mathrm{hr}}{ }^{-1}$ which is equal to the urban area of Brazil. Environmental radiation and radioactivity monitoring is crucial to generate the baseline database from natural sources before starting operation of the country's first nuclear power plant. The national baseline database is very important for comparison before and after operation of the nuclear power plant. This study is very useful to know the artificial radionuclides releasing (if any) to the environment from manmade sources like hospitals. Therefore, real-time gamma radiation measurement is very essential in and around radiological facilities (hospitals) for the safety of the public. From this study, it is observed that the assessment of the radionuclide level of the area did not detect the presence of any artificial radionuclides and thus no significant impact of the extensive usage of radioactive materials within and around the area of Ramna Thana and no radiation burden to the environment. Finally, it can be concluded that adequate safety and radiation protection of nuclear \& radiological facilities had been ensured which is required for minimizing of unnecessary exposure to populations from man-made sources.

\section{Acknowledgement}

The authors would like to thank concerned personnel of Health Physics Division, Atomic Energy Center, Dhaka for their support. 


\section{References}

1. M. Charles, J. Radiol. Prot. 21, 83 (2001). https://doi.org/10.1088/0952-4746/21/1/609

2. Agency for Toxic Substances and Disease Registry (ATSDR): Toxicological Profile for Ionizing Radiation (Atlanta, GA: US, Department of Health and Human Services, Public Health Service, 1999).

3. UNSCEAR Report, Sources and Effects of Ionizing Radiation, Annex A: Dose Assessment Methodologies (New York, United Nations Scientific Committee on the effects of atomic radiation, 2000) 1.

4. S. Selvasekarapandian, K. S. Lakshmi, G. M. Brahmanandhan, and V. Meenakshisundaram, Int. Congr. Ser. 1276, 327 (2005). https://doi.org/10.1016/j.ics.2004.10.026

5. W. F. Wilson, A Guide to Naturally Occurring Radioactive Materials (Oklahoma, PennWell Books, 1994) pp.128

6. S. Hazrati, S. Harrad, M. Alighadri, H. Sadeghi, A. Mokhtari, N. Gharari, and S. Rahimzadeh, Iran. J. Environ. Health Sci. Eng. 7, 157 (2010).

7. F. S. Al-Saleh, Appl. Radiat. Isot. 65, 843 (2007). https://www.ncbi.nlm.nih.gov/pubmed/17391973

8. F. H. Al-Ghorable, Environ. Res. 98, 160 (2005). https://www.ncbi.nlm.nih.gov/pubmed/15820721

9. H. Arvela, Int. Congr. Ser. 1225, 9 (2002). https://doi.org/10.1016/S0531-5131(01)00532-5

10. L. Rybach, D. Bachler, B. Bucher, and G. Schwarz, J. Environ. Radiat. 62, 277 (2002). https://doi.org/10.1016/S0265-931X(01)00169-2

11. F. Sagnatchi, M. Salouti, and A. Eslami, Radiat. Prot. Dosim. 132, 346 (2008). https://doi.org/10.1093/rpd/ncn285

12. M. B. Tavakoli, Med. Sci. Monit. 9, 7 (2003).

13. H. L. Beck, J. D. Campo, and C. Gogolak, In-Situ Ge(Li) and NaI(Tl) Gamma-ray Spectrometry (New York, US DOE, Environmental measurement Lab., HASL-258; 1972).

14. I. Nikl and L. B. Sztanyik, Radiat. Prot. Dosim. 24, 387 (1988). https://doi.org/10.1093/oxfordjournals.rpd.a080309

15. International Commission on Radiation Units and Measurements (ICRU Report 53: GammaRay Spectrometry in the Environment, 1994).

16. I. Othman and T. Yassine, Sci. Tot. Environ. 170, 119 (1994). https://doi.org/10.1016/0048-9697(95)04610-D

17. M. Tzortzis, H. Tsertos, S. Christofides and G. Christodoulides, Radiat. Measur. 37, 221(2003). https://doi.org/10.1016/S1350-4487(03)00028-3

18. X. S. Clouvas and M. Antonopoulos-Domis, Radiat. Prot. Dosim. 112, 267 (2004).

19. X. S. Clouvas and M. Antonopoulos-Domis, Radiat. Prot. Dosim. 94, 233 (2001). https://www.ncbi.nlm.nih.gov/pubmed/11487806

20. A. B. Petalas, E. Vogiannis, D. Nikolopoulos, and C. P. Halvadakis, Radiat. Prot. Dosim. 113, 336 (2005). https://doi.org/10.1093/rpd/nch455

21. M. M. Auwal, M.Sc. thesis, Ahmadu Bello University, Zaria, Nigeria, 2000.

22. UNSCEAR, United Nations Scientific Committee on the Effect of Atomic Radiation Sources Effect and Risk of Ionizing Radiation (New York, United Nations Scientific Committee on the Effect of Atomic Radiation, 1998).

23. A. Clouvas, S. Xanthos, and M. Antonopoulos-Domis, Radiat. Prot. Dosim. 94, 233 (2001). https://doi.org/10.1093/oxfordjournals.rpd.a006495

24. S. Harb, J. Nucl. Particle Phys. 6, 88 (2016).

25. Owner's Manual, GARMIN eTrex HC Series, available at https://static.garmincdn.com/pumac/eTrexLegendHCx_OwnersManual.pdf

26. Bangladesh Population Census, (Bangladesh Bureau of Statistics, 2011).

27. User Manual GAMMA SCOUT, https://www.gamma-scout.com/EN/Handbuch.php

28. UNSCEAR, United Nations Scientific Committee on the Effects of Atomic Radiation, Sources, Effects and Risks of Ionizing Radiation (United Nations, New York, 1988). 


\section{In-Situ Environmental Gamma Radiation Monitoring}

29. A. A. Sadiq and E. H. Agba, Facta Universities Series: Workings and Living Environmental Protection 9(1), 19 (2012). http://facta.junis.ni.ac.rs/walep/walep201201/walep201201-03.pdf

30. N. N. Jibiri and S. T. U. Obarhuna, J. Nat. Sci. Res. 3, 25 (2013). https://www.iiste.org/Journals/index.php/JNSR/article/view/4883

31. UNSCEAR, Source and Effects of Ionizing Radiation. Report to General Assembly, with Scientific Annexes. United Nations Scientific Committee on the Effects of Atomic Radiation (United Nations, New York, 2000), pp. 265-273.

32. UNSCEAR, REPORT Vol. 1, Sources and Effects of Ionizing Radiation, Annex B: Exposures of the Public and Workers from Various Sources of Radiation (United Nations Scientific Committee on the effects of atomic radiation, New York, 2008). 